\title{
Standards for Enterprise Architectures
}

\author{
Alicia Valdez Menchaca ${ }^{1}$, Griselda Cortes ${ }^{2}$, Sergio Castaneda ${ }^{2}$ and Alejandro Luna ${ }^{2}$ \\ 1. Research Center, Faculty of Engineering Mechanical and Electrical, University Autonomous of Coahuila \\ 2. Academic Unit Computer Systems, Faculty of Engineering Mechanical and Electrical, University Autonomous of Coahuila
}

\begin{abstract}
The manufacturing industry in Mexico has great potential for growth, especially small and medium enterprises (smes), with an area of opportunity for the integration of its key processes to information technology, through which you can provide information quickly and effectively to support strategic decision making. A methodology for the development of schemes that provide the foundation for the use of information in support of business strategy enterprise architecture is composed of partial architectures and data architecture / applications, business architecture and technology architecture. This paper presents an analysis of standards known in the scientific literature on enterprise architecture to develop a proposal for midsize companies. It also discusses open source tools for managing enterprise architecture. The results offer great expectations for sme's to implement enterprise architectures in their processes this analysis is part of a research project that seeks to design and implement enterprise architectures in sme's, the project is currently in analysis.
\end{abstract}

Key words: Enterprise architecture, SME’s, key processes.

\section{Introduction}

EA (enterprise architecture) is a methodology that aims to provide companies a framework for the use of information in business processes in ways that support the business strategy [1], the EA is used as a strategic tool to support mechanism and the alignment between business strategy and ICT's (information and communication technologies) [2].

Throughout the development of computer sciences, have emerged different methodological frameworks that provide a guide or method for setting the EA; between these frameworks are:

- The Zachman Framework;

- The DoDAF(department of defense architecture framework);

- TOGAF(the open group architecture framework);

- FEA (federal enterprise architect).

Emphasizing as a common prime factor setting the strategic alignment of the company with ICT's to contribute for increased productivity and

Corresponding author: Alicia Valdez Menchaca, Ph.D., research fields: computer systems in management, enterprise architecture. E-mail: aliciavaldez@uadec.edu.mx. competitiveness of enterprises.

This paper presents an analysis of the first three mentioned frameworks for enterprise architectures, tools, and a design model for medium manufacturing enterprises.

These firms provide a high rate of employment in the Mexico's northern industry, which provide raw material to automotive cluster with global enterprises located in the cluster.

\section{Basic Concepts}

\subsection{The Zachman Framework}

With the complexity of organizations, the volume of data and transactions has increased significantly impacting information systems.

The EA started as management information systems in the early 60's in the United States company IBM (international business machines) by "Information Systems, Control and Planning Staff” (ISCM) area. Where the bases of the methodology known as BSP (business systems planning), considered one of the methodologies that started the EA with John Zachman, who developed a framework for defining architectures 
for information systems, created what subsequently became the "Zachman Framework" [3].

The framework was created to provide a disciplined management information systems, and professional communication that allows the improvement and integration of tools and development methodologies.

Related information systems strategy with business strategy, aligning both strategies to establish order and control in investment resources information systems to ensure business success [4].

Using the analogy of the development of information systems with building a house, with the terms: Owner's View, Designer's View, and Builder's View, in order to increase appropriate levels of detail for each view.

The two ideas that originate the Zachman framework were [4]:

- There is a set of architectural renderings produced on the process of building engineering complex product, representing the different perspectives of different stakeholders;

- The same product can be described, for different purposes in different ways, resulting in different types of descriptions.
Based on these two ideas, the framework combines two dimensions: the perspectives and types of descriptions; perspectives or views are rows and types of descriptions are the columns.

Perspectives are: Scope, Business Model, Model Systems, Model Technology, Representations and Operation Detailed Company. The types of descriptions are: data, functions, Networking, People, Time and Motivation, which represents the questions: What, How, Where, Who, When and Why. In Table 1 the Zachman Framework is shown.

Each cell in the table contains a set of elements that represent diagrams or documents on the specific architecture and level of detail; e.g., column of architecture functions or processes with the line of objectives and scope, a list of processes running the business is taken into the cell.

Ylimaki and Halttunen [5] mentioned to consider the rules to implement the Zachman framework:

- All columns are equally important, since all are abstractions of the company;

- Do not add columns or rows as the original six questions (What, How, Where, Who, When and Why) from the basis of knowledge about a subject or object being described;

Table 1 The Zachman framework.

\begin{tabular}{|l|l|l|l|l|l|l|}
\hline & $\begin{array}{l}\text { DATA } \\
\text { What }\end{array}$ & $\begin{array}{l}\text { FUNCTION } \\
\text { How }\end{array}$ & $\begin{array}{l}\text { NETWORK } \\
\text { Where }\end{array}$ & $\begin{array}{l}\text { PEOPLE } \\
\text { Who }\end{array}$ & $\begin{array}{l}\text { TIME } \\
\text { When }\end{array}$ & $\begin{array}{l}\text { MOTIVATION } \\
\text { Why }\end{array}$ \\
\hline $\begin{array}{l}\text { Objective/Scope } \\
\text { (contextual) } \\
\text { Role: Planner }\end{array}$ & $\begin{array}{l}\text { List of things } \\
\text { important in the } \\
\text { business }\end{array}$ & $\begin{array}{l}\text { List of Business } \\
\text { Processes }\end{array}$ & $\begin{array}{l}\text { List of Business } \\
\text { Locations }\end{array}$ & $\begin{array}{l}\text { List of important } \\
\text { Organizations }\end{array}$ & List of Events & $\begin{array}{l}\text { List of Business } \\
\text { Goal \& Strategies }\end{array}$ \\
\hline $\begin{array}{l}\text { Enterprise Model } \\
\text { (contextual) } \\
\text { Role: } \text { Owner }\end{array}$ & $\begin{array}{l}\text { Conceptual Data/ } \\
\text { Object Model }\end{array}$ & $\begin{array}{l}\text { Business Process } \\
\text { Model }\end{array}$ & $\begin{array}{l}\text { Business } \\
\text { Logistics System }\end{array}$ & $\begin{array}{l}\text { Work Flow } \\
\text { Model }\end{array}$ & Master Schedule & $\begin{array}{l}\text { Business } \\
\text { Plan }\end{array}$ \\
\hline $\begin{array}{l}\text { System Model } \\
\text { Rogical })\end{array}$ & $\begin{array}{l}\text { Logical Data } \\
\text { Rosigner }\end{array}$ & $\begin{array}{l}\text { System } \\
\text { Architecture } \\
\text { Model }\end{array}$ & $\begin{array}{l}\text { Distributed } \\
\text { Systems } \\
\text { Architecture }\end{array}$ & $\begin{array}{l}\text { Human Interface } \\
\text { Architecture }\end{array}$ & $\begin{array}{l}\text { Processing } \\
\text { Structure }\end{array}$ & $\begin{array}{l}\text { Business Rule } \\
\text { Model }\end{array}$ \\
\hline $\begin{array}{l}\text { Technology } \\
\text { Model (physical } \\
\text { Role } \text { :Builder }\end{array}$ & $\begin{array}{l}\text { Physical Data/ } \\
\text { Class Model }\end{array}$ & $\begin{array}{l}\text { Technology } \\
\text { Design Model }\end{array}$ & $\begin{array}{l}\text { Technology } \\
\text { Architecture }\end{array}$ & $\begin{array}{l}\text { Presentation } \\
\text { Architecture }\end{array}$ & Control Structure & Rule Design \\
\hline $\begin{array}{l}\text { Detailed } \\
\text { Reprentation } \\
\text { (out of context } \\
\text { Role:Programmer }\end{array}$ & Data Definition & Program & $\begin{array}{l}\text { Network } \\
\text { Architecture }\end{array}$ & $\begin{array}{l}\text { Security } \\
\text { Architecture }\end{array}$ & Timing Definition & Rule Speculation \\
\hline $\begin{array}{l}\text { Functioning } \\
\text { Enterprise } \\
\text { Role: User }\end{array}$ & Usable Data & $\begin{array}{l}\text { Working } \\
\text { Function }\end{array}$ & Usable Network & $\begin{array}{l}\text { Functioning } \\
\text { Organization }\end{array}$ & $\begin{array}{l}\text { Implemented } \\
\text { Schedule }\end{array}$ & Working Strategy \\
\hline
\end{tabular}

Source: IBM [3], Extended [6]. 
- Each cell must include a primitive architecture as a simple graphical model describing the company from a viewpoint corresponding to one of the six descriptions;

- You may decide not to produce a deliverable in a given cell;

- The integration of cells belonging to a line represents a complete model from the perspective of the line in question.

Zachman mentioned Enterprise Architecture is the "Primitive set and presented graphically descriptive artifacts that constitute the knowledge infrastructure of the company" [4] quoted by Ref. [5].

To implement the Zachman Framework, some experts recommend a working method that generates documents that are required at each stage.

\subsection{The Department of Defense Architecture} Framework.

In 1994, the Department of Defense of the United States of America created the TA-FIM (technical architectural framework for information management), based on Zachman Framework [7].

In 1996, the Congress of the United States of America passed a law called "Clinger-Cohen Act of 1996, which specifies that federal agencies should improve the efficiency of investment on information technologies, establishing the Council of Managers of Information Technology (CIO's Council) group, which originated the FEAF (federal enterprise architecture framework) [7].

TAFIM was withdrawn by the Department of Defense and the association donated to The Open Group, who later developed TOGAF (the open group architecture framework) Standard [8].

DoDAF has defined "An architecture consists of multiple views or perspectives, facilitating the integration and promoting interoperability between capabilities and integrated architectures" [9].

DoDAF focuses on data as necessary to develop architectures that are intended to facilitate effective decision making through organized information element.

DoDAF methodology consists of six steps shown in Fig. 1.

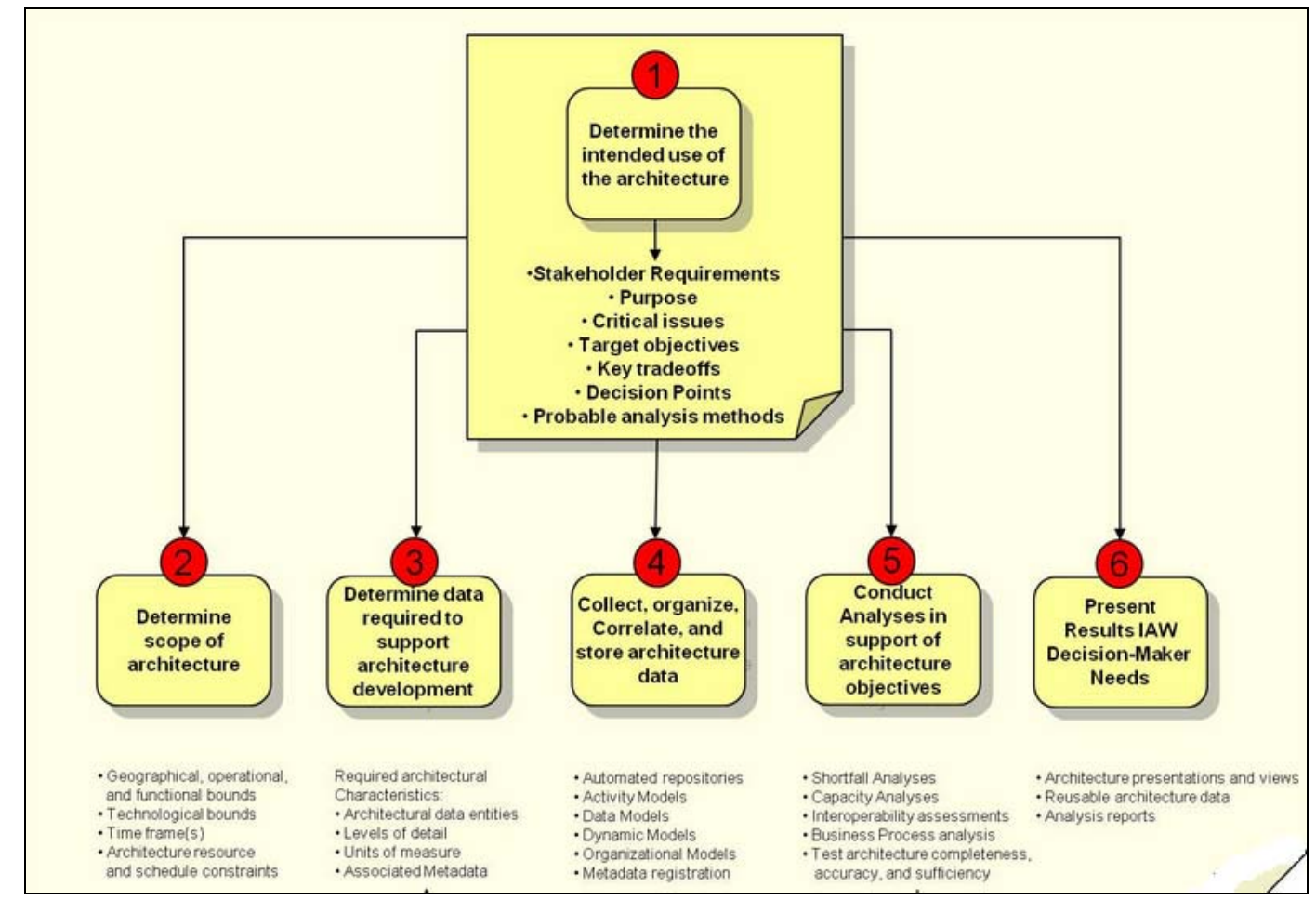

Fig. 1 Steps of DoDAF Standard, source [9]. 
Determine the use of architecture: the purpose and use of architecture is defined as the descriptions process, the method of development of architecture, the categories necessary data, the potential impact will be conducted and the processes by which the success of the effort will be measured in terms of performance and customer satisfaction.

Determine the scope of architecture: The scope defines the boundaries or limits, establishes the set of problems for architecture helps define the context and defines the level of detail required for the content of architecture.

Determine the data required to support the development of architecture: The level of detail required for each data entity along with its attributes, including identification data necessary process and other data required to effect change in the current process. The reuse of data previously used in other analyzes can simplify this step.

Collect, organize, relate and store data architecture: In this step you collect and organize data through the use of techniques designed to use the views (e.g., activities, processes, organization or data models) for presentation and purposes decision-making. Data is stored in a recognized marketing tool.

Conduct the analysis in support of the objectives of architecture: Analysis of data architecture determines the level of compliance with the requirements of the process owner. Identified additional process steps to complete the description of the architecture.

Document results requires the decision maker: The final step is the development of the architecture process involves creating query-based views of the data, this data can be presented in different formats such as graphical representations, dashboards views, and others formats.

To conclude this standard was created to meet the specific needs of decision makers and can be replicated in companies. The main activities lie in the method of six steps to create descriptions of architectures [8].

\subsection{The Open Group Architecture Framework (TOGAF).}

It is an enterprise architecture methodology and framework used in organizations to improve business efficiency [9]. As mentioned in the previous section this standard is based on DoDAF, was subsequently updated by The Open Group has developed successive versions until the current version 9.1.

Based on the ADM (architecture development method); ADM is divided into 9 phases, an overview of the architecture describing how the new capacity going to align business goals and strategic objectives with ICT's. Fig. 2 shows the phases of the ADM Method.

The Preliminary phase includes the preparation and initiation of activities to build the capacities of architecture requires understanding the business environment, create a committee of senior management, establishing consensus on the scope, establish principles, the structure of governance and personalization framework.

Phase A: Architecture Vision: At this stage the scope, constraints, expectations vision of architecture is also created, validates the business context, statements of work of architecture created are defined.

Phase B: Business Architecture: In this phase the fundamental organization of the business and its goals, objectives, business processes, functions, services, human resources, organizational structure, the principles governing its design and evolution is analyzed. Shows how the organization meets the goals and objectives of the business.

Activities of Phase B:

- Select reference models, views and tools.

- Define the description of the reference architecture.

- Define the architecture object.

- Conduct a gap analysis.

- Define the components of the roadmap. 


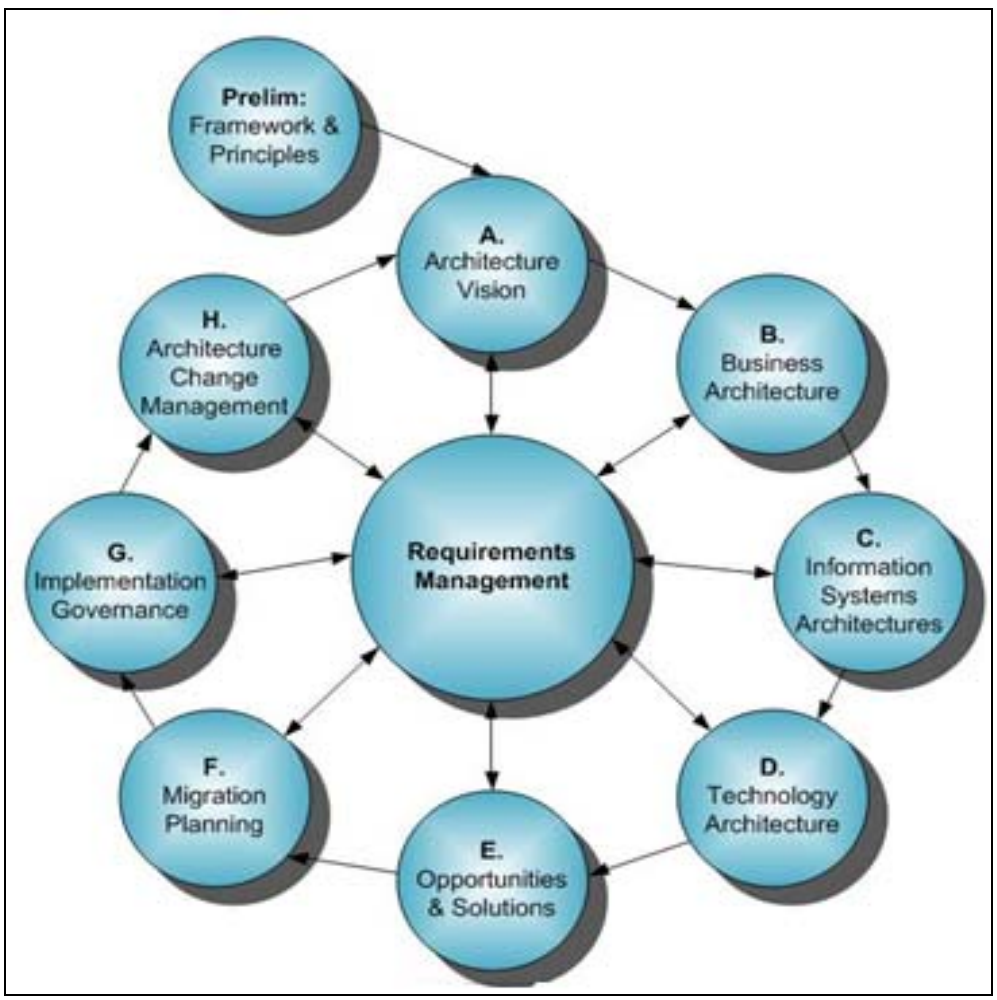

Fig. 2 TOGAF phases.

In the "B" phase, the BA with the fundamental business organization and its goals, objectives, business processes, functions, services, human resources, organizational structure, the principles governing its design and evolution are analyzed.

Phase D: Architecture Technology: Analyzes the fundamental organization of information technology systems, including hardware, software and communications technology, the interrelationships between each of these components and their environment, and the principles governing its design and evolution.

Architecture Technology Activities:

- Analyze the hardware, software and communications technology available in the company and how they support the goals and objectives of the business.

Phase E: Opportunities and Solutions: In this phase the initial deployment planning is done, the major implementation projects identify the decision on the approach to be taken as buying, re-use or open source outsourcing; establishing priorities and dependencies.

Phase F: Migration Planning: In this phase migration is planned projects identified in phase-dos $\mathrm{E}$ doing a cost-benefit risk assessment it ends with a detailed implementation plan analysis.

Phase G: Implementation of Governance: Provides oversight for implementation, define constraints on architecture implementation projects, governs and manages the architecture, monitors the conformance of the implementation.

Phase H: Architecture Change Management: Provides continuous monitoring of the process of change management, ensures that changes to the architecture will be managed in a cohesive and structured manner.

Establishes and supports the $\mathrm{AE}$ provides a flexibility to evolve rapidly in response to changes in technology or business environment.

The TOGAF Standard is a complete methodology to plan, develop, implement and govern an EA in any organization. At each stage deliverables artifacts such 
as catalogs, matrices, diagrams are created.

Having analyzed the three standards, which is recommended for a company?

Brons and Basten [10] recommend a mixed approach to create its own standard based on the characteristics of the standards presented, other authors [11] present the Zachman framework as a taxonomy and have recommended the TOGAF standard for building enterprise architecture own signature.

\subsection{Software for Enterprise Architecture}

One open source software for managing the $\mathrm{AE}$ is

Essential Architecture Manager version 4.3, which is a toolset that supports EA practices, offering some features required like repository, metamodel that support some partial architectures like business, data, information, techonology and strategy [12].

These features can be gruped into two areas: Modeling and views of the model for reporting and analysis. The Fig. 3 shows the functionality of the software.

Pre-requisites software are required for Essential:

- Java Runtime 1.5 or above.

- Protege Ontology Editor 3.4 or above.

- Apache Tomcat 5.5 or above.
- Graphviz 2.26.

This toolset provides a graphical environment that is needed to create the views, models and descriptions of partial architectures.

The Fig. 4 displays the editor for Essential.

\section{Proposal for EA}

The proposal for EA includes the TOGAF Standard with the ADM Method using the Essential toolset for repository and modeler of the views required. The Fig. 5 shows the proposal.

The TOGAF Standard, where general bases are the preliminary analysis, business architecture, the architecture of information systems, and technology architecture, which are the architectures to develop for this research project. Using the Essential Toolkit for respository of the data and artifacts to obtain. The Fig. 6 displays the general data flow of the proposal.

Every partial architecture requires a completely set of documents, data, interviews with responsibles of each function of the firm. In the BA (business architecture), important documents where the business plan is defined, mission, vision, goals, strategy, competitive advantage, clients, providers, products, layout, organization chart, and others, are analyzed for construct it.

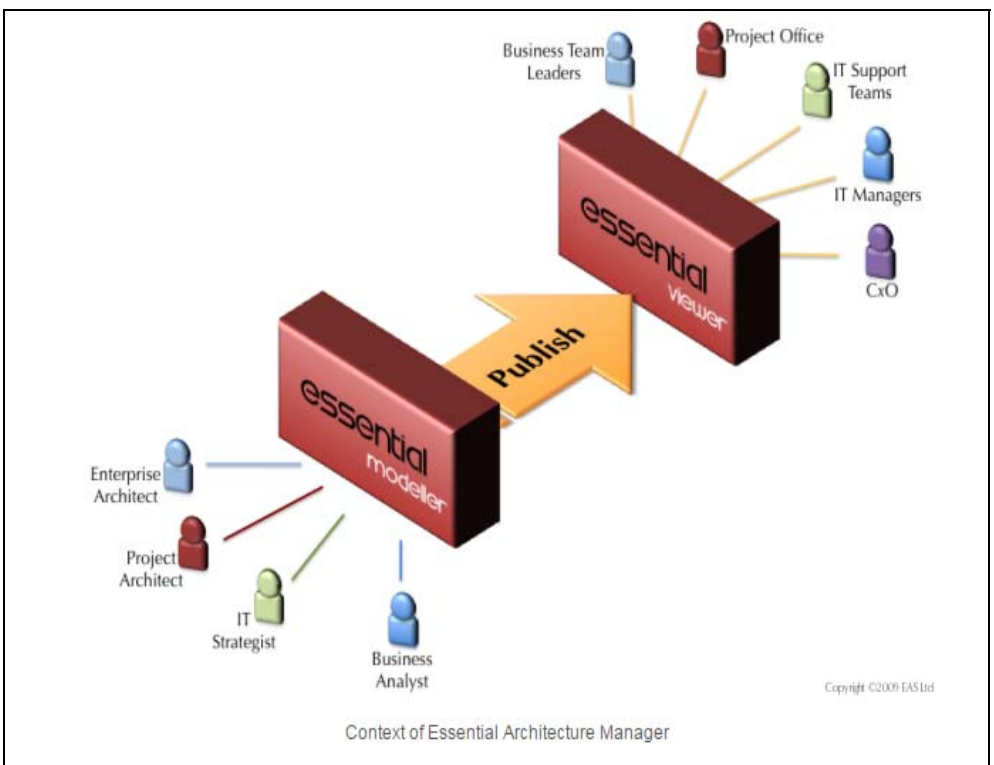

Fig. 3 Functions of essential software. 


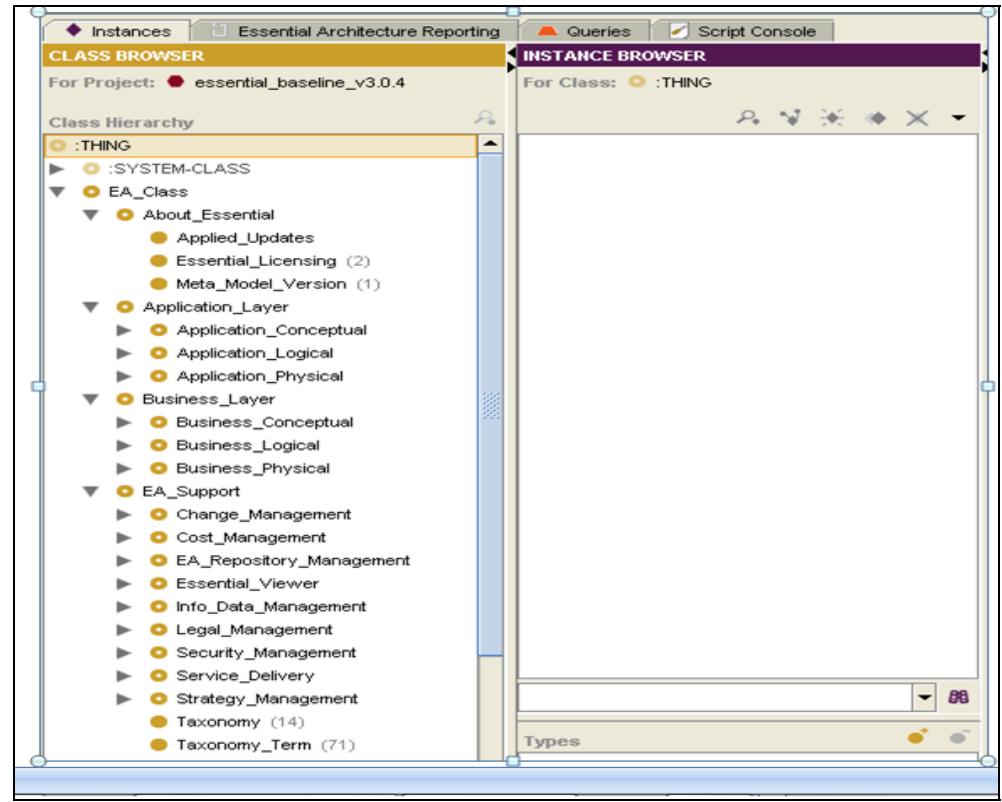

Fig. 4 Editor for Essential Architecture Manager.

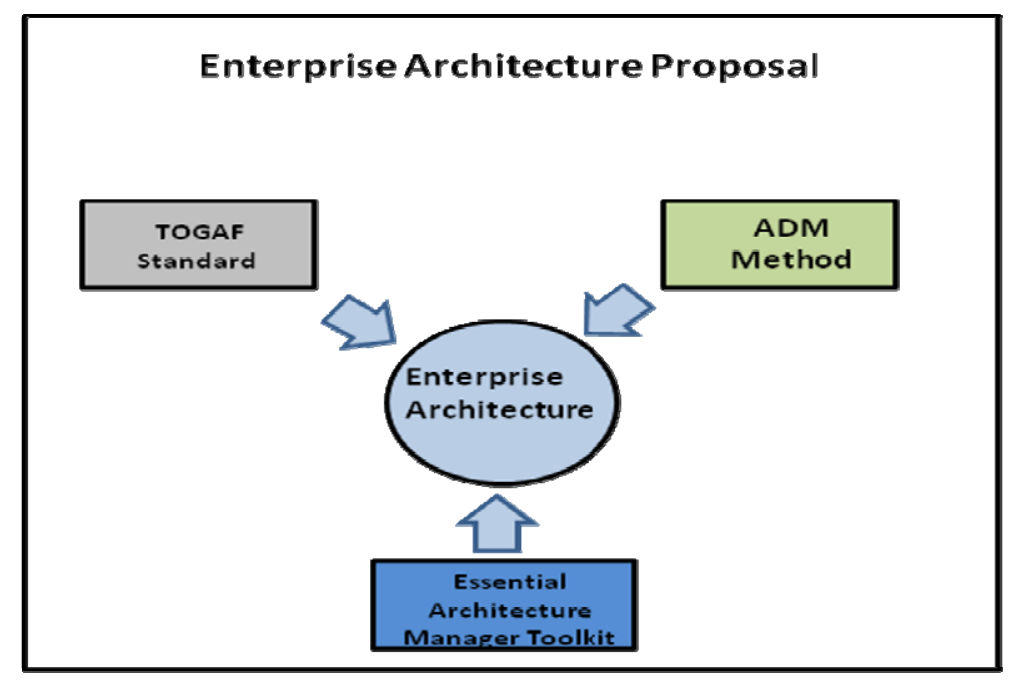

Fig. 5 Enterprise architecture proposal.

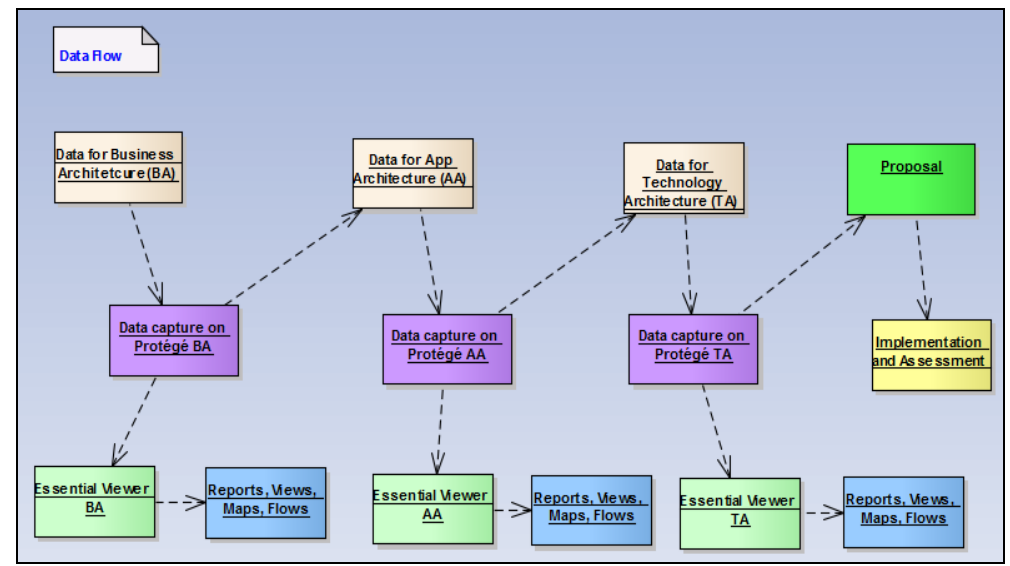

Fig. 6 Data flow for the EA. 
This research project is in development in the manufacturing metal mechanic sector for the medium sized enterprises in northern Mexico.

\section{Conclusion}

The designing process of the EA in medium organizations in metal mechanic industry in Mexico reflects the needs of this industry sector, to upgrade their management and technological skills to compete in global markets.

EA must be focused on the importance of the technology strategy aligned with the business strategy, to gain competitive advantage from the use of ICT's, to enable them to be inserted into global markets with a clear plan.

This project helped to meet the needs of SMEs companies to propose affordable solutions that make business management resources and technology to solve problems.

The contribution of the paper focuses on the approach to the problems of the company, with the help of Enterprise Architecture, software tools, and the implementation model.

This industry would be integrated to a more specialized chain in the international markets.

\section{References}

[1] Bernard, S. 2012. Enterprise Architecture Linking
Strategy, Business and Technology. USA: Autor House.

[2] Spewak, S. 2000. Enterprise Architecture Planning. Wiley publisher.

[3] Zachman, J. 1987. "A Framework for Information Systems Architecture.” IBM Sytems Journal 26: 276-92.

[4] Zachman, J. 2000. "Enterprise Architecture Artifacts vs. Application Development Artifacts (Part 2).” Business Rules Journal 5 (March).

[5] Ylimaki, T., and Halttunen, V. 2006. "Method Engineering in Practice: A Case of Applying the Zachman Framework in the Context of Small Enterprise Architecture Oriented Projects.” Information Knowledge Systems Management 5: 189-209.

[6] Sowa, J., and Zachman, J. 1992. "Extending and Fomalizing the Framework for Information Systems Architecture.” IBM Systems Journal 31: 590-616.

[7] Sessions, R. 2007. "Comparison of the top four Enterprise-Architecture Methodologies.” MSDN.

[8] The Open Group TOGAF V9.1-M1, "Management Overview in ADM Basic Principles 2011.” The Open Group, United States of America, 2014, pp. 1-34.

[9] Department of Defense of the United States of America, “DoD Architecture Framework Version 2.0.”, 2012, pp 1-14.

[10] Basten, D., and Brons, D. 2012. EA Frameworks, Modelling and Tools in Strategic Management: Challenges, Best Practices, and Future Developments, Management for Professionals. Germany: Springer.

[11] Schekkerman, J. 2004. How to Survive in the Jungle of Enterprise Architecture Frameworks. Canada: Trafford Publishing.

[12] LTD, E.A.S., “The Essential Project”, 2014, http://www.enterprise-architecture.org/ [retrieved: 01-2014]. 